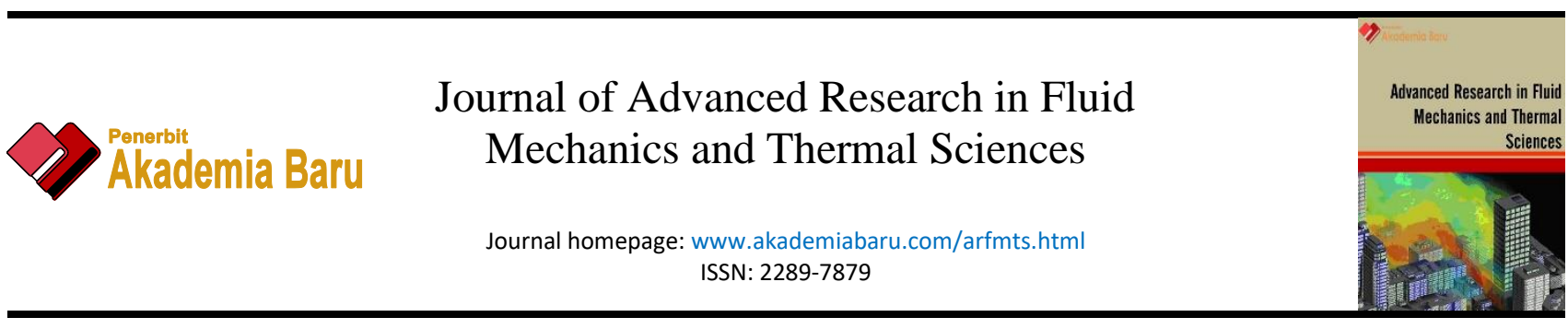

\title{
Potential of Steam Recovery from Excess Steam in Sterilizer at Palm Oil Mill
}

\author{
Yoganathan Palaniandy ${ }^{1,}$, Nor Mariah Adam ${ }^{1}$, Yiu Pang Hung ${ }^{1}$, Fatin Hana Naning ${ }^{1}$ \\ 1 Faculty of Agriculture and Food Science, Universiti Putra Malaysia, 97008 Bintulu, Sarawak, Malaysia
}

\section{ARTICLE INFO}

\section{Article history:}

Received 10 July 2020

Received in revised form 23 November 2020

Accepted 25 November 2020

Available online 12 December 2020

Keywords:

Steam Recovery; Sterilizer; Excess Steam;

Steam Ejector; Steam Morphology

\section{ABSTRACT}

Energy saving is something that being focus deeply either larger or smaller industry in this current era especially steam and electricity. In a crude palm oil mill, tons of fibers and woods are used for burning process as a boiler fuel to generate steam. As steam is good heat transfer medium, it is use for the regular process of heating the product or materials by direct and batch heating to raise the temperature in order to change the characteristic. In typical palm oil mill, every $1000 \mathrm{~kg}$ of fresh fruits bunches (FFB) required $250 \mathrm{~kg}$ of steam energy for the sterilization process. It is not surprising that the exhaust lost that release to the atmosphere from the total steam usage is about $70 \%$, which can conclude as energy waste. By referring to this issue, the cost of replace consumable boiler fuel increase tremendously. Besides that, the huge amount of heat release caused the thermal pollution that may have significant effects in the ecological balance and lead to changes in the aquatic fauna and flora. This paper reviews and critically discusses the waste of steam energy and the morphology involved in excess steam from sterilizer. The system that combined with few steps of steam recovery were developed to recovery the low-pressure steam to form the mid-pressure steam that can able to reuse at the process plant. The steam ejector technology is use in this research to recover and reuse the excess steam leading to lower energy consumption and fuel costs. The overall idea is about combining the low-pressure excess steam with high-pressure steam that directly supply from back pressure receiver to form the midpressure steam. The Ansys software used as to identify the change of parameter of excess steam and through the software, the percentage of motive steam needed to combine with excess steam finalized. Via recovery and reuse the excess steam from sterilizer, the total energy consumption will be minimized at least $20 \%$ which can able to reduce the massive expenses for boiler fuel that benefit the palm oil mill owners.

Copyright $@ 2021$ PENERBIT AKADEMIA BARU - All rights reserved

\section{Introduction}

conventional palm oil milling process, the fresh fruits bunches transferred from loading ramp ether through conveyor system or cages into sterilizer to cook the fruits. Steam is the prime medium

\footnotetext{
* Corresponding author.

E-mail address: yoga.glg224@gmail.com
}

https://doi.org/10.37934/arfmts.79.1.1726 
that used to sterilize the fruits with specified pressure and temperature. The entire sterilization process takes about 70 to 90 minutes to completely cook the fruits. Even there are few sterilizer types in market such as horizontal, vertical and continues sterilizer, an ideal sterilization process is exclusively reflected by the quality of oil produced. The air is removed from sterilizer by sweeping in the steam by few cycles such as single-peak, double-peak and triple-peak. Steam consumption varies as per peak cycle where $140 \mathrm{~kg} /$ ton FFB for single peak and $224 \mathrm{~kg} /$ ton FFB for triple peak [1]. All the commercial process of sterilization is carried out at $131^{\circ} \mathrm{C}$ with a steam pressure of $50 \mathrm{psi}$ (3.5Bar) for better sterilization [2].

Industrial waste heat is the energy that is generated in industrial processes which is not put into any practical use and is wasted or dumped into the environment where exhaust steam release from sterilizers still has a sizable quantity of heat that is currently discharge directly to the atmospheric [3]. Conventionally, the higher the temperature that released into atmosphere the higher the quality of the waste heat that can use for optimization of waste heat recovery process. Figure 1 shows the typical co-generation system used in palm oil mills is consists of the boiler that produces high pressure and the temperature is further raised in the super heater. The steam expands in a backpressure turbine and exhausts in an accumulator. The excess steam from turbine is distribute to other heating process [4].

There are many different solutions for the increase of the heat recovery efficiency have been proposed and available in market. Among these is the well-known steam ejector where a mixed working fluid of variable composition is used to provide a better match between the temperatures and pressure of steam. The main operating parameters considered for heat recovery steam generator (HRSG) are the number of pressure levels, the mass ratios between motive steam and excess steam and the saturation temperatures [5].

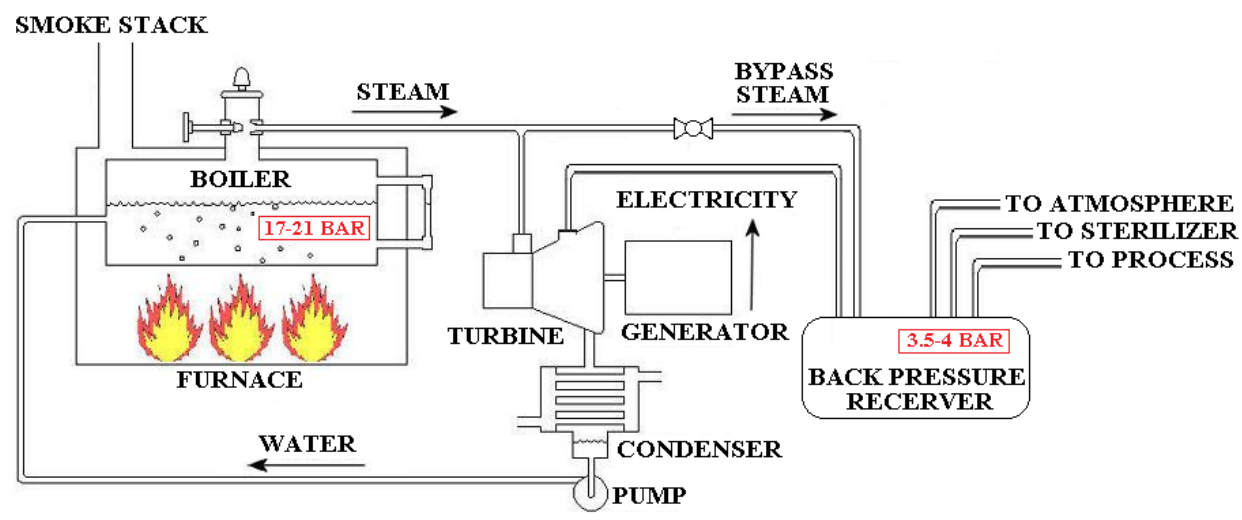

Fig. 1. The typical co-generation system in palm oil mill

\section{Methodology}

\subsection{Thermodynamic Calculation}

In palm oil sterilizer, using continues heating where the steam will directly in contact with product. Thus, the mean of heat transfer can be express as below

$Q=C p \times d t \times \frac{m}{t}$

where $Q$ is mean heat transfer rate $(\mathrm{kW}(\mathrm{kJ} / \mathrm{s})), m / t$ is mass flow rate of the product $(\mathrm{kg} / \mathrm{s}), C p$ is specific heat of the product $\left(\mathrm{kJ} / \mathrm{kg}\right.$.) and $d t$ is change in fluid temperature $\left({ }^{\circ} \mathrm{C}\right)$. The amount of steam consumption able to calculate once identify the heat transfer rate as below 
$m s=\frac{q}{h e}$

where, $m s$ is mass of steam $(\mathrm{kg} / \mathrm{s}), q$ is calculated heat transfer $(\mathrm{kW})$ and he is evaporation energy of the steam $(\mathrm{kJ} / \mathrm{kg})$. The quantity or the amount of available waste heat can be calculate using the equation shown below

$Q=V \times \rho \times C p \times \Delta T$

where $Q$ is the heat content, $V$ is the flowrate of the substance $\left(\mathrm{m}^{3} / \mathrm{s}\right), \rho$ is density of the flue gas $\left(\mathrm{kg} / \mathrm{m}^{3}\right), C p$ is the specific heat of the substance $(\mathrm{J} / \mathrm{kg}$.$) and \Delta T$ is the difference in substance temperature $(\mathrm{K})$.

\subsection{Case Study}

The material balance and energy balance were performed based on the raw data collected from the article published by Malaysian palm oil board (MPOB). The case study for this article is based on the palm oil mill capacity of $60 \mathrm{t} / \mathrm{h}$ of FFB. The actual motive steam and excess steam parameter obtained from the site survey conducted at typical $60 \mathrm{t} / \mathrm{h}$ of FFB palm oil mill in Malaysia. The raw data collected at site are such as excess steam pressure, steam temperature and steam volume.

\subsection{Concept Generation}

Figure 2 shows the new concept that developed to collect and recycle the excess steam in sterilizer at palm oil mill. The exhaust steam that released into atmospheric will collect by install a new pipeline to collect waste steam. This steam will be reduced by pressure reducing valve to maintain the flowrate. The steam accumulator added into this system to storage the excess steam and allowed to maintain the sufficient volume for steam recovery process. At this stage, the steam condensate from the wet steam will be removed by the steam trap mechanism. The next process continues with mixing the low-pressure steam and high-pressure steam to form the mid pressure steam.

The steam ejector is developed to suits the motive steam (high pressure) with excess steam (low pressure) as per process requirements. The steam ejector designed as the first portion of design will be the steam inlet, the second portion will be the mixing chamber to both different type of steam and finally the last portion will be the diffuser of steam with high pressure and flowrate. The recovered steam transferred to the main steam supply pipeline from back pressure receiver.

Recovered steam will be act as top up steam for the sterilization process where 3.5 bar of steam from back pressure receiver will add up together with existing steam and through this the energy consumption can able to reduce. 


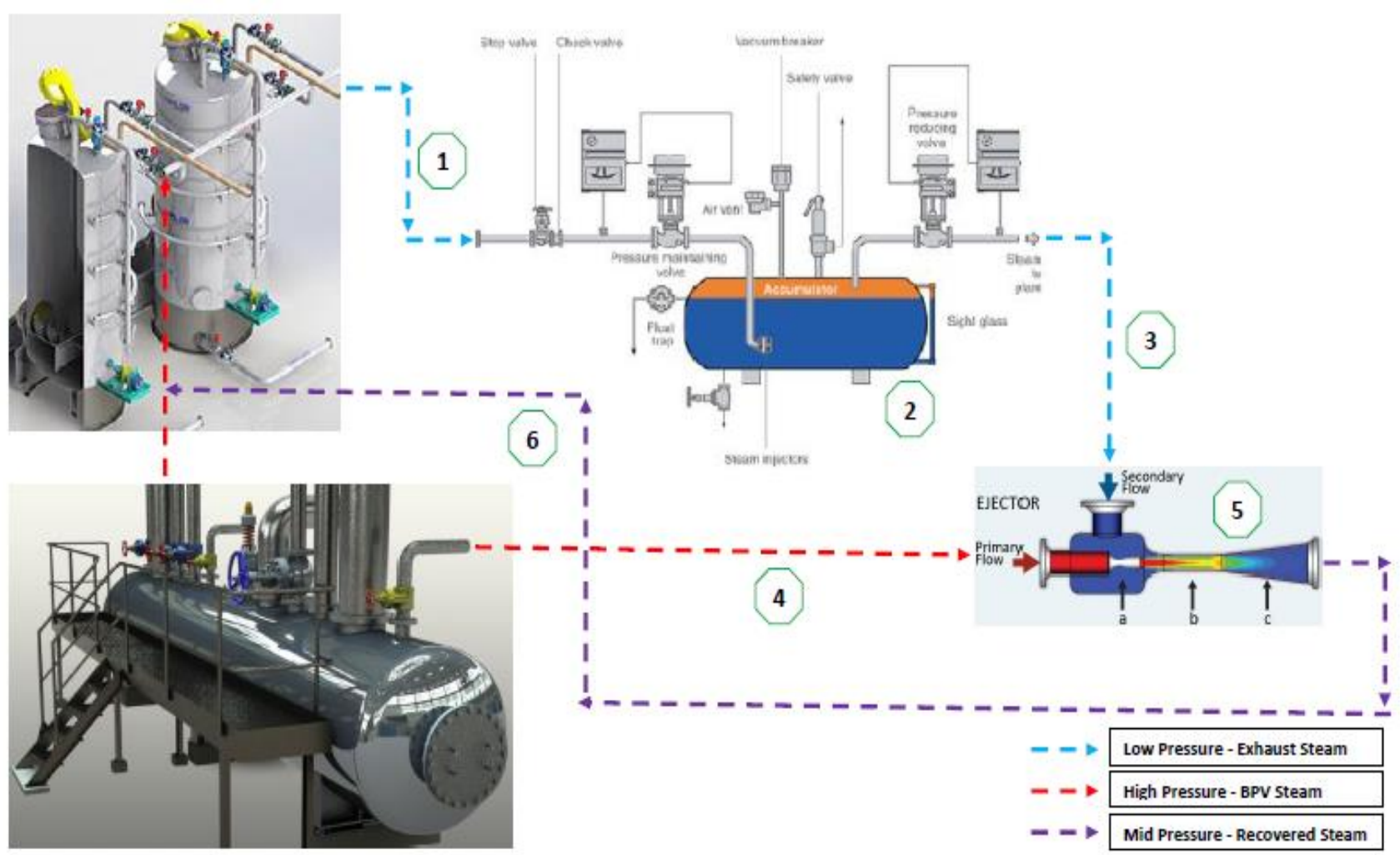

Fig. 2. Excess steam from sterilizer recovery system

\section{Findings}

\subsection{Sterilizer Material and Energy Balance}

Figure 3 shows the two main ways or place of steam excess in sterilizer (pressure vessel) which are at the steam exhaust point and the steam condensate point. The excess energy in superheated steam is transient and itis eventually dissipated by the items in the sterilizer chamber. The excess steam at power plant is currently discharge to the atmosphere despite its thermal energy potential due to the vapour-domination of the steam [6].

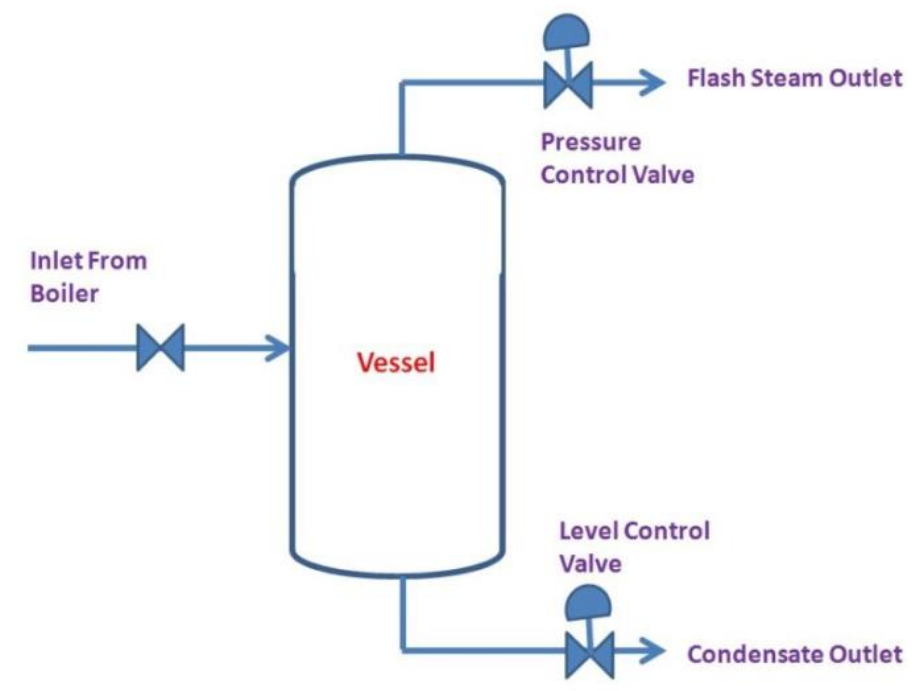

Fig. 3. Steam distribution in sterilizer [1] 
Figure 4 shows the process block diagram of mass balance and energy balance of sterilizer in typical palm oil mill. In simple understanding, every $1000 \mathrm{~kg}$ of fresh fruit bunches (FFB) required 250 $\mathrm{kg}$ of steam for sterilization process. After the sterilization process, the steam energy excess with two possible area such as through condensate and exhaust loss. By considering this, the total exhaust loss for palm oil mill of $60 \mathrm{t} / \mathrm{h}$ of FFB will be approximately 10 tons per every sterilization process. The steam condensate from sterilizer unable to recovery due to the oil and biomaterials contaminants. Anyhow, the condensate steam that contain of oil will be send to oil recovery process.

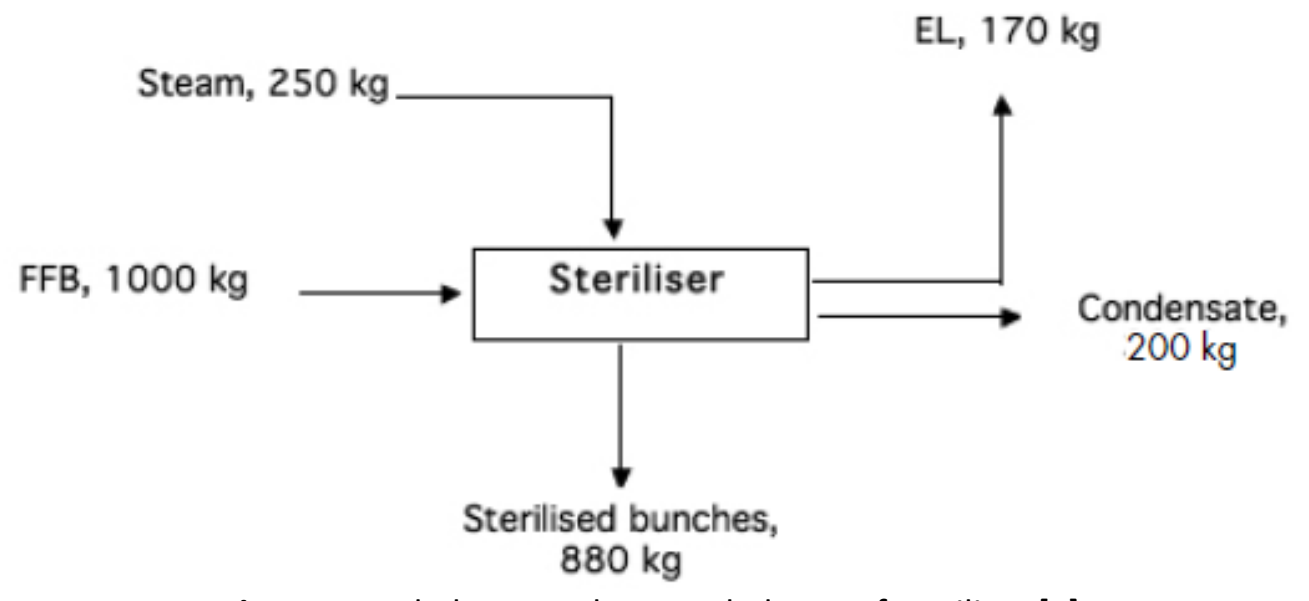

Fig. 4. Mass balance and energy balance of sterilizer [7]

\subsection{Energy Waste in Sterilizer}

Table 1 shows the waste energy at typical $60 \mathrm{t} / \mathrm{h}$ of FFB processing palm oil mill. According to the author, the steam consumption for three-peak sterilization process required 24 tons of steam for sterilization process. The total steam blown out 12 tons, which covered $50 \%$ of the total steam consumption. In this case, the steam holding pressure is 4 Bar and the exhaust steam also maintain the pressure. By referring to steam table for 4 bar of saturated steam, the energy loss will be $2.739 \mathrm{MJ} / \mathrm{kg}$. The amount and volume of waste steam increase as the numbers of sterilizer in palm oil mill added up as per process requirements.

Table 1

The energy lost from the sterilizer during exhaust and blow-off operation [1]

\begin{tabular}{ll}
\hline Waste energy calculation & \\
\hline FFB processed & $60 \mathrm{tph}$ \\
Steam consumption (say at 40\% of FFB processed) & $24 \mathrm{tph}$ \\
Sterilizer condensate produced (20\% of FFB processed) & $12 \mathrm{tph}$ \\
Steam used for deaeration (say 5\%) & $3 \mathrm{tph}$ \\
Steam blown out during exhaust (15\%) & $9 \mathrm{tph}$ \\
Total steam blown out & $12 \mathrm{tph}$ \\
Heat contained in saturated steam at 4 bar, (steam table) & $2.739 \mathrm{MJ} \mathrm{kg}^{-1}$ \\
For 18,000 kg steam per hour (energy lost in blown out steam) & $32,860 \mathrm{MJ} \mathrm{hr}^{-1}$ \\
\hline
\end{tabular}

\subsection{Morphology of Excess Steam}

Table 2 shows the parameter of excess steam in sterilizer. The operating parameter of sterilizer excess steam is 4 Bar as exhaust pressure, $130{ }^{\circ} \mathrm{C}$ of temperature with $2750 \mathrm{~kJ} / \mathrm{kg}$ enthalpy of saturated steam. The steam quality is unsaturated, which is wet in condition. Meanwhile if the 
Reynolds number (Re) in a saturated steam system is less than 10000 (104) the flow will be laminar and if greater than 10000 (104) the flow regime is turbulent.

The characterized in that the excess steam is condensed to an unclean condensate in a steam regeneration unit. The collected thermal energy in the unclean condensate is recovered by being transferred to a district heating medium in a heat exchanger for district heating. The effect of inlet wetness on transonic wet-steam and moist-air flows through turbine and compressor cascade channels. Water vapor in steam flows or airflows conditionally condenses into small water droplets. Condensation of wet-steam flows in a steam turbine may be governed by homogeneous nucleation and no equilibrium condensation where the temperature and pressure decrease to far below their saturated values. The latent heat released during the vapor-to-liquid phase change of water increases the temperature of the turbine [8].

Table 2

Morphology Characteristics of Excess Steam

\begin{tabular}{|c|c|c|c|c|}
\hline Parameters & Elements & & & \\
\hline $\begin{array}{l}\text { Operation } \\
\text { parameter }\end{array}$ & Pressure (3.5-4 Bar) & $\begin{array}{l}\text { Temperature }\left(130^{\circ} \mathrm{C}-\right. \\
\left.160^{\circ} \mathrm{C}\right)\end{array}$ & $2750 \mathrm{~kJ} / \mathrm{kg}$ & $\begin{array}{l}\text { Duration (60 - } \\
90 \text { Min) }\end{array}$ \\
\hline Steam quality & Unsaturated steam (Wet) & & & \\
\hline Excess steam flow & Laminar flow & Turbulent flow & & \\
\hline
\end{tabular}

\subsection{Heating Process}

Figure 5 shows the type of heating methods which consists of direct heating and indirect heating. The direct heating systems use superheated steam that is apply directly to the product, either by injecting the steam in-line into the product or by allowing product to pass through a steam-filled chamber. Direct methods also have advantages over indirect heating by tubular or plate heat exchangers in that the direct contact with the heating medium and profile of the treated product, limiting product quality loss from excess heat exposure [9].

Indirect heating uses a heat transfer medium to apply the heat to the tank that can vary from external heating of the tank using the tank wall as the heating medium to utilizing a heat transfer medium to carry the heat to the tank. The biggest advantage to indirect heating is, the heater can typically be serviced without draining the tank and often allows watt density exposed to the process fluid to be lowered by spreading the heat over a larger surface [10].
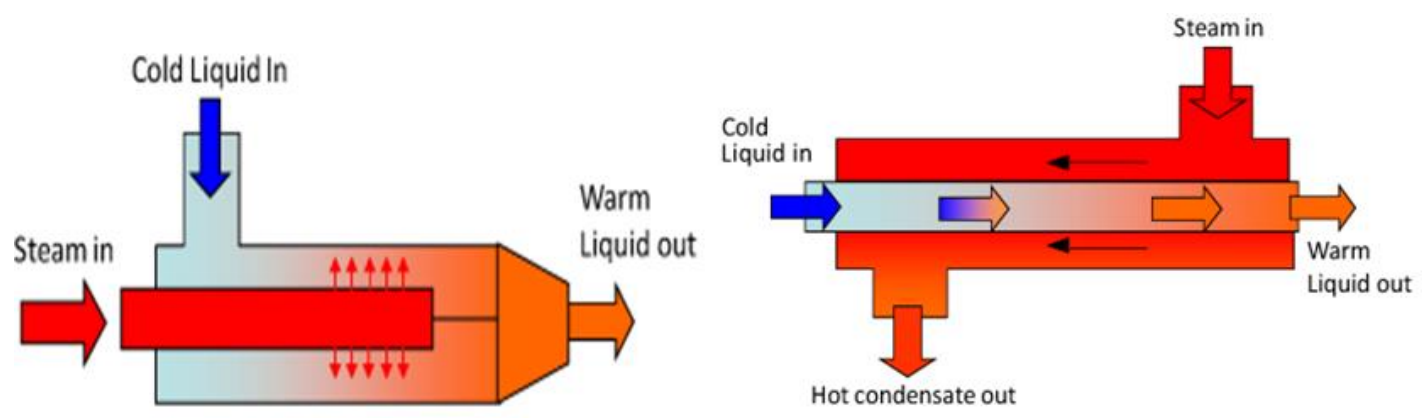

Fig. 5. Direct and indirect heating methods

\subsection{Pipe Heating System}

Figure 6 shows the heat pipe where it is a device that can transfer heat from one place to another with the help of condensation and vaporization of a working fluid. A heat pipe consists of three different sections: the evaporator section, the adiabatic transport section and the condenser section. 
When heat is applied to one end of the pipe, it is conducted through the pipe wall and wick structure and the working fluid inside the pipe evaporates. As a result, a vapour pressure is generated which drives the vapour through the adiabatic transport section to the other end of the pipe. The vapour then condenses by losing the latent heat of vaporisation through the wick structure and wall of the pipe to the heat sink [11].

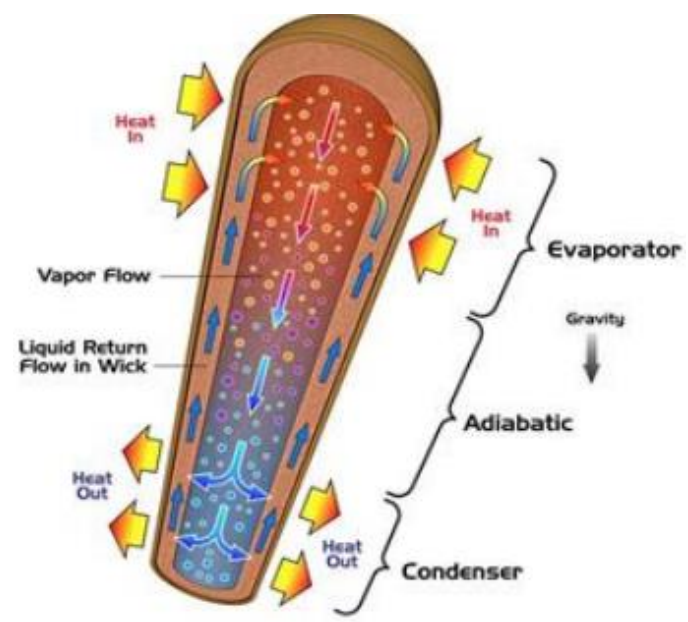

Fig. 6. Schematic of a Heat Pipe

\subsection{Steam Accumulator}

The direct storage of saturated or superheated steam in pressure vessels is not economic due to the low volumetric energy density. Figure 7 shows the steam accumulators use sensible heat storage in pressurized saturated liquid water. Steam produced by lowering the pressure of the saturated liquid during discharge. Since, water is used both as storage medium and working medium high discharge rates are possible, while the capacity is limited by the volume of the pressure vessel. The volume specific thermal energy density depends strongly on the variation of the saturation temperature resulting from the pressure drop during discharge, characteristic values are in the range of $20-30 \mathrm{~kW} \mathrm{~h} / \mathrm{m}^{3}$. During the charging process, the liquid water is increase by condensation of superheated steam or increase by feeding saturated liquid water into the system [12].

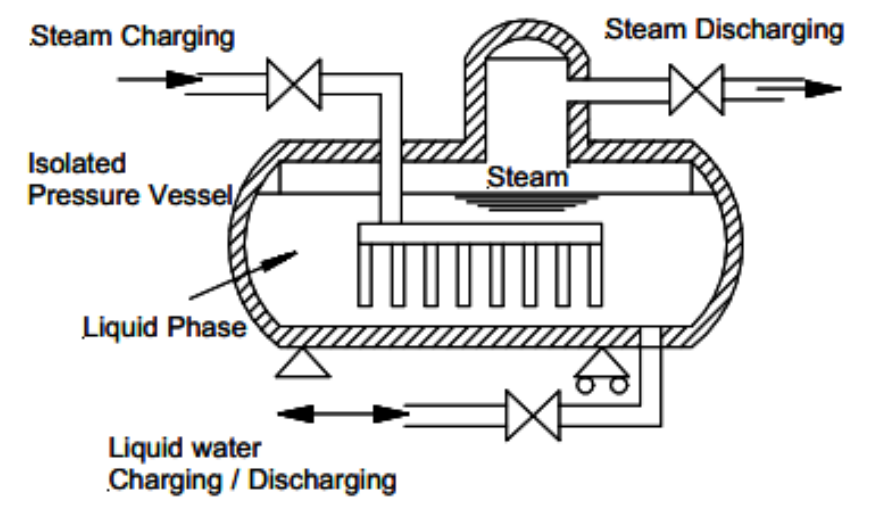

Fig. 7. Scheme of sliding pressure steam accumulator 


\subsection{Steam Ejector}

Steam ejector use as an energy-saving unit that gives critical importance to the overall performance of steam system. To achieve a good entrainment performance, the steam ejector strictly operating within double-critical conditions. However, this solution could not take full recovery of the primary steam pressure and with some sacrifice of the mixed steam energy quality. In order to seek a breakthrough for performance improvement of the steam ejector, systematic simulations of the internal flow field need to identify especially at the mixing process. Figure 8 shows the double critical conditions at the constant-pressure mixing theory disclosed where the entrained flow is accelerate in the entrainment passage without mixing with the primary steam immediately until reaches the choked state. The high-pressure region happens to be located at the upstream of choking cross section, acting like a baffle for the entrained flow [13].

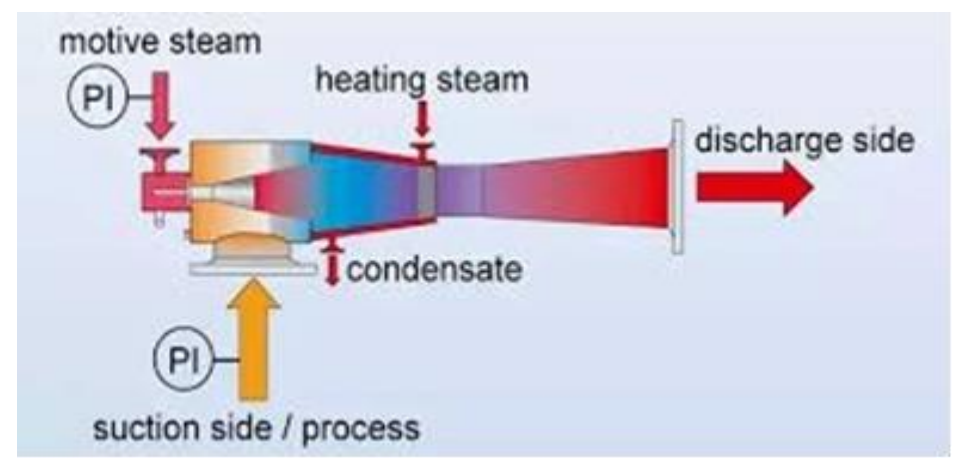

Fig. 8. Mechanism of steam ejector

\section{Conclusions}

In conclusion, industrial waste heat is the energy lost in industrial processes to the environment. Waste heat recovery in industry covers methods of collection and re-use of the lost heat of industrial processes that can then be used to provide useful energy and reduce the overall energy consumption. Heat loss is mainly classified into high temperature, medium temperature and low temperature grades and waste heat recovery systems are correspondingly introduced for each range of waste heat. The selection of heat recovery methods and techniques largely depends on key factors such as the quality, quantity and the nature of heat source in terms of suitability and effectiveness. The identification of the waste sources is an important aspect when looking into waste heat recovery methods for industrial processes in order to achieve optimum results and efficiency. In this regard, a comprehensive review is presented for waste heat recovery methodologies and state of the art technologies used in industrial processes.

As per Table 3, it was investigated that there are many different heat recovery technologies available for capturing the waste heat and they mainly consist of energy recovery heat exchangers in the form of a waste heat recovery unit. The new steam ejector system mainly comprises common waste heat recovery systems and all work by the same principle to capture, recover and exchange heat with a potential energy content in a process. Whereas, economisers recover low - medium waste heat and are mainly used for heating the low-pressure medium materials which can easily change its characteristics. On the other hand, it was explored that waste heat from sterilizer are suitable to recover heat from medium - high temperature exhaust gases and are mainly used to generate steam for energy recovery. 
Table 3

Steam recovery technologies

\begin{tabular}{|c|c|c|c|}
\hline Technologies & $\begin{array}{l}\text { Temperature } \\
\text { Range }\end{array}$ & Benefits & Limitations \\
\hline $\begin{array}{l}\text { Waste Heat } \\
\text { Boilers }\end{array}$ & Medium - High & $\begin{array}{l}\text { The system is suitable to recover } \\
\text { heat from medium - high } \\
\text { temperature exhaust gases and is } \\
\text { used to generate steam as an } \\
\text { output. }\end{array}$ & $\begin{array}{l}\text { An additional unit such as an } \\
\text { auxiliary burner or an after } \\
\text { burner might be needed in the } \\
\text { system if the waste heat is not } \\
\text { sufficient to produce the } \\
\text { required amount of steam. }\end{array}$ \\
\hline $\begin{array}{l}\text { Plate Heat } \\
\text { Exchanger }\end{array}$ & Medium - High & $\begin{array}{l}\text { Plate heat exchangers have high } \\
\text { temperature and pressure } \\
\text { operating limits and are used to } \\
\text { transfer heat from one fluid to } \\
\text { another when cross contamination } \\
\text { needs to be avoided. }\end{array}$ & $\begin{array}{l}\text { Parameters such as frequent } \\
\text { variation in temperature and } \\
\text { load must be studied and based } \\
\text { on that suitable heat exchanger } \\
\text { design must be chosen to avoid } \\
\text { failure of the structure of the } \\
\text { heat exchanger for the } \\
\text { application }\end{array}$ \\
\hline $\begin{array}{l}\text { Heat Pipe } \\
\text { Systems }\end{array}$ & Medium - High & $\begin{array}{l}\text { Heat pipes have very high effective } \\
\text { thermal conductivities, which } \\
\text { results in a minimal temperature } \\
\text { drop for transferring heat over long } \\
\text { distances and long life that requires } \\
\text { no maintenance, as they } \\
\text { incorporate passive operation. } \\
\text { They have lower operation costs } \\
\text { when compared to the other types } \\
\text { of heat exchangers. }\end{array}$ & $\begin{array}{l}\text { To achieve an optimum } \\
\text { performance from the heat } \\
\text { exchanger, appropriate design, } \\
\text { material, working fluid and wick } \\
\text { type based on the application } \\
\text { and temperature range of the } \\
\text { waste heat must be studied and } \\
\text { chosen. }\end{array}$ \\
\hline Heat Pump & Low - Medium & $\begin{array}{l}\text { Heat pumps transfers heat from a } \\
\text { heat source to a heat sink using a } \\
\text { small amount of energy and can be } \\
\text { used to offer economical and } \\
\text { efficient alternative of recovering } \\
\text { heat from various sources to } \\
\text { improve overall energy efficiency. } \\
\text { Heat pumps in particular are good } \\
\text { for low-temperature WHR, as they } \\
\text { give the capability to upgrade } \\
\text { waste heat to a higher } \\
\text { temperature and quality. }\end{array}$ & $\begin{array}{l}\text { In order to use this system, the } \\
\text { method of capturing the waste } \\
\text { heat based on its source and } \\
\text { grade must firstly be analysed } \\
\text { and in that respect, appropriate } \\
\text { heat exchanger and system } \\
\text { installation needs to be set up. }\end{array}$ \\
\hline $\begin{array}{l}\text { Direct Contact } \\
\text { Condensation } \\
\text { Recovery }\end{array}$ & Medium - High & $\begin{array}{l}\text { the system uses a direct mixture } \\
\text { heat exchanger without a } \\
\text { separating wall and can be used to } \\
\text { transfer heat from immiscible } \\
\text { liquid - liquid and solid - liquid or } \\
\text { solid-gas }\end{array}$ & $\begin{array}{l}\text { Due to absence of a separating } \\
\text { wall in this heat exchanger, } \\
\text { particles from the flue gas can } \\
\text { be mixed with the water, which } \\
\text { may require filtering before } \\
\text { exiting the heat exchanger. }\end{array}$ \\
\hline
\end{tabular}

Waste heat recovery opportunities in food industry were also investigated and it was discovered that the potential sources of waste heat in this industry are mainly associated with heating of hot streams of water or air and heat from processing operations. Some waste heat sources such as waste water and cooker exhaust recovery may be difficult and uneconomical to utilise because of grease and food waste products in the exhaust. It was discovered that, the major heat recovery equipment are mainly categorised based on the temperature range and the type of fluid being recovered in the process and each has a different usage. 
This paper indicates that improving energy efficiency by utilising waste heat recovery in industrial processes is achievable based on different approaches and with the use of different state of the art technologies. However, in order to obtain the most optimum efficiency for a system through waste heat recovery, the type of process in question should be always examined and analysed and then a method of waste heat recovery for optimising energy efficiency should be assigned.

\section{Acknowledgement}

The authors would like to thank for the myriad support of mill senior managers and mill engineers who provided the advices and constructive comment throughout the data collection process. The Faculty of Agriculture and Food Science, Universiti Putra Malaysia supported this study by providing authorize to access the software for do simulation and conduct pilot study at laboratory.

\section{References}

[1] Abdullah, N., and F. Sulaiman. "The oil palm wastes in Malaysia." Biomass now-sustainable growth and use 1, no. 3 (2013): 75-93.

https://doi.org/10.5772/55302

[2] Yunus, R., Z. A. Zurina, S. Syafiie, V. Ramanaidu, and U. Rashid. "Effect of high pressurized sterilization on oil palm fruit digestion operation." International Food Research Journal 23, no. 1 (2016).

[3] Glover, Z. J. "Dairy Processing and Spray Drying." (2018).

[4] Nasrin, A. B., N. Ravi, W. S. Lim, Y. M. Choo, and A. M. Fadzil. "Assessment of the performance and potential export renewable energy (RE) from typical cogeneration plants used in palm oil mills." Journal of Engineering and Applied Sciences 6, no. 6 (2011): 433-439.

[5] Casarosa, Claudio, F. Donatini, and Alessandro Franco. "Thermoeconomic optimization of heat recovery steam generators operating parameters for combined plants." Energy 29, no. 3 (2004): 389-414.

https://doi.org/10.1016/S0360-5442(02)00078-6

[6] Assad, M. El Haj, E. Bani-Hani, and M. Khalil. "Performance of geothermal power plants (single, dual, and binary) to compensate for LHC-CERN power consumption: comparative study." Geothermal Energy 5, no. 1 (2017): 17. https://doi.org/10.1186/s40517-017-0074-z

[7] Menon, N. R. "Thermodynamics Applied to Palm Oil Milling" no. 2 (2017): 1-9.

[8] Yamamoto, Satoru, Shota Moriguchi, Hironori Miyazawa, and Takashi Furusawa. "Effect of inlet wetness on transonic wet-steam and moist-air flows in turbomachinery." International Journal of Heat and Mass Transfer 119 (2018): 720-732. https://doi.org/10.1016/i.ijheatmasstransfer.2017.12.001

[9] Lee, A. P., D. M. Barbano, and M. A. Drake. "The influence of ultra-pasteurization by indirect heating versus direct steam injection on skim and 2\% fat milks." Journal of Dairy Science 100, no. 3 (2017): 1688-1701. https://doi.org/10.3168/jds.2016-118996

[10] Roux, Stephanie, Mathilde Courel, Ines Birlouez-Aragon, Francesco Municino, Mario Massa, and Jean-Pierre Pain. "Comparative thermal impact of two UHT technologies, continuous ohmic heating and direct steam injection, on the nutritional properties of liquid infant formula." Journal of Food Engineering 179 (2016): 36-43. https://doi.org/10.1016/i.jfoodeng.2016.02.001

[11] Jouhara, Hussam, Amisha Chauhan, Theodora Nannou, S. Almahmoud, Bertrand Delpech, and Luiz C. Wrobel. "Heat pipe based systems-Advances and applications." Energy 128 (2017): 729-754.

https://doi.org/10.1016/i.energy.2017.04.028

[12] Steinmann, Wolf-Dieter, and Markus Eck. "Buffer storage for direct steam generation." Solar Energy 80, no. 10 (2006): 1277-1282. https://doi.org/10.1016/i.solener.2005.05.013

[13] Tang, Yongzhi, Zhongliang Liu, Yanxia Li, Can Shi, and Chen Lv. "A combined pressure regulation technology with multi-optimization of the entrainment passage for performance improvement of the steam ejector in MED-TVC desalination system." Energy 175 (2019): 46-57.

https://doi.org/10.1016/i.energy.2019.03.072 